\title{
PSYCHOLOGICAL ASPECTS OF THE FORMATION OF READINESS FOR DECISION-MAKING IN EXTREME SITUATIONS BY BORDER GUARDS
}

\section{Lesia Lytvynchuk}

\section{INTRODUCTION}

The research of the psychological readiness of border guards for professional activity is presented in the works of: V. Afanasenko, A. Akulich, B. Badmaeva, O. Boyko, O. Borysyuk, O. Bykova, S. Budnik, E. Matusyak, A. Mateyuk, S. Mula, P. Korchemnogo, L. Kuznetsova, C. Kuznetsova, V. Loskutov, S. Maksimenko, A. Moshchenko, L. Orban-Lembrik, V. Osyodlo, O. Safina, V. Sisoeva, A. Stoliarenko, V. Pokalyuk, B. Furmanets and others, who emphasized the need to form motivation for professional activity, the ability to manage their emotional states while being in psycho This is a difficult situation. A number of studies have addressed the issue of preparing future border guards for professional activity (V. But, V. Varenik, A. Voedilo, V. Gribeniuk, Y. Ivanova, V. Kalyuzhny, A. Kaplya, O. Kokun, I. Kovalchuk, O. Kolesnichenko, A. Krylov, R. Kuzina, I. Ponomarenko, E. Potapchuk, V. Ryutin, O. Samokhvalov, S. Filippov, etc.) Due to the military actions in the east of Ukraine, there is a demand for border service professionals who not only function effectively, but also show the capacity for personal development, Self-improvement, creativity in their own activities, ready to take responsibility in an extreme situation. Under such conditions, it becomes important to form the psychological readiness of the future border guard to make a decision in extreme conditions, which is possible due to the improvement of the vocational training system.

\section{Main part}

Building the statehood of Ukraine, building a new democratic society brings to the fore the problems associated with the training of a competent specialist who is able to adequately perceive changes in public life and professional growth. Border guards are faced with situations that lead to the following conditions: uncertainty, lack of 
time to make the best decision, tension, responsibility, frustration, fear for their own lives, etc. Border activity is a specific field in which special knowledge, skills, skills of a specialist are found, where his professionally significant qualities and abilities are realized. Such a profession is associated with the need to possess the intellectual, psychological, physical, moral potential for risk readiness and a high level of patriotism.

A brief analysis of the concept of development of the State Border Guard Service of Ukraine shows that the activity of border guards takes place under stressful and difficult conditions. Patrolling the terrain within a border region may be accompanied by a high risk of extremality, occupational stress, requiring a specialist to make quick decisions in the face of uncertainty, and the like. The State Border Service of Ukraine emphasizes that border guards should be able to: make independent and non-standard decisions, carry out analysis, planning and control of operational and service activities, organize border service in different conditions, using both traditional and innovative means and methods. protection of the border. Researchers outline the differences between decision-making processes in ordinary life and decision-making in a crisis, which is one of the most important causes of psychological stress on the military when making a decision. There are the following differences between making a combat decision and making a simple, everyday decision:

1. The unknown of the situation. In battle, it is very rare for situations where the situation is completely clear, for each "for" there is a similar "against", it is necessary to make decisions based on only probable data, which can be false.

2. The inability to achieve the "perfect" result, the fear of mistakes. Even after full and proper preparation, actions can be unsuccessful, and understanding that even "right" actions can lead to "wrong" results is exacerbated by anxiety,

3. Fear of responsibility. Responsibility can be different - before oneself, moral, before management, criminal, etc. But in any case, the military does not want to have problems because of the negative result of their actions.

4. Lack of time to think and consider all possible options. Events can develop so quickly that a decision must be made lightning-fast. 
5. Unclear purpose of the action or apparent innocence of the action. Often, the overall purpose of the action is unclear, including that it can be deliberately hidden by command to prevent the enemy from guessing at a planned operation.

E. Zeer, E. Simanyuk, note that the attitude to risk is determined mainly by the conditions of the environment or by some individual psychological characteristics of the person, such as aggression or anxiety level. People with a strong need for self-affirmation and more aggressive personalities make decisions in crisis situations emotionally. Perseverance enables, despite little success, to achieve the desired result in each individual action. Therefore, in the work of the military is important to take into account personal characteristics in the perception of the situation. Researchers describe the mechanism of decision-making in crisis conditions as follows: situation assessment, risk and error assessment, choice of decision-making procedure (creative, situational, standard, intuitive).

M. Dyachenko, V. Lefebvres emphasize that decision making in risk conditions depends to a certain extent on the gender of the manager. Although more experienced executives, both men and women, are more willing to make risk-taking decisions than workers with less work experience, there are some differences between them. Yes, when making decisions in crisis situations, men tend to be at higher risk.

This is due to their inherent traits such as independence in actions, greater than women, the degree of aggression, the need for dominance, self-affirmation. Women choose more cautious strategies, but they have a willingness to take risk when making decisions under more specific conditions than men. For example, in the conditions of stress, nervous tension, when experiencing feelings of frustration, such opportunities are reduced. Researchers also present an algorithm for decision-making in crisis conditions: sharpening of attention, orientation in the situation, determination of the priority signal, parameter estimation, evaluation of the situation as a whole, decisionmaking, algorithm of action, action, result. Therefore, the factors that influence border decision making are stress or psychological exhaustion. The manifestations of stress can be varied, from excessive activity, and attempts to ignore difficulties or inactivity, lack of initiative and negligence. 
Psychological readiness is understood as an active mental state, a prerequisite for purposeful activity, its regulation, resilience, efficiency, which helps to successfully fulfill their duties, to properly use knowledge, experience, personal qualities, maintain Self-control and rebuild activity with the appearance of unforeseen obstacles.

Therefore, the content of the concept of "psychological readiness for professional activity", including the following components: the presence of psychological knowledge, skills, emotional state, physical abilities of the individual, etc.

Structural components of psychological readiness for activity in extreme situations are presented in the works of M. Dyachenko, L. Kandybovych, Y. Zabrodin, V. Ponomarenko, T. Kanivets, K. Durai-Novakova, Y. Zabrodin.

O. Proskura $^{1} \quad$ (Almukhanova \& oth., 2007) interprets psychological readiness for activity as a personal formation that includes such structural components as motivational, cognitive, and operational components. K. Durai-Novakova defines the structure of psychological readiness for work through motivational, psychological, and professional components. A. Derkach identifies in the psychological readiness for activity such structural components as: cognitive, emotional, motivational. Y. Zabrodin outlines such structural components of psychological readiness as: operating, which is interpreted as the organization and separation of areas of professional activity formed by the psychological system; motivational, which involves the formation, which at the expense of mastered personal values and preferences becomes a system of professional interests and inclinations; functional - generalized, complex human condition. Thus, the main structural components of psychological readiness for professional activity are motivational, professional, operational, cognitive, cognitive. The components are said to be interconnected and dynamically interconnected. Researchers have emphasized the importance of all components of the structure,

1 Almukhanova, A. B. \& oth. (2007). Bol'shaya psykholohycheskaya entsyklopedyya : samoe polnoe sovremennoe yzdanye : Bolee 5000 psykholohycheskykh termynov y ponyatyy [Big psychological encyclopedia: the most complete modern publication: More than 5000 psychological terms and concepts]. Moscow: Эksmo Publ. (in Russian). 
including the determining ones are the motivational and cognitive components.

M. Dyachenko, L. Kandybovych in their works define the following structural components of psychological readiness for activity in extreme situations: motivational (responsibility, feeling duties); orientation (knowledge of the conditions of activity); operating (possession of methods and techniques, necessary knowledge, skills, abilities, processes of analysis, synthesis, correlation, generalization, etc.); volitional (self-control, mobilization); evaluation (selfassessment of their readiness).

The authors interpret readiness to act in an extreme situation as a stable characteristic of the individual and call it "long-term readiness". Unlike the situational state of readiness, it operates on an ongoing basis and, since it is formed in advance, is an essential prerequisite for the success of the activity. Positive features of long-term readiness are the conformity of its content structure and conditions of professional activity, ease of actualization and inclusion in the task, plasticity, combination of stability and dynamism. Summarizing the above, it should be noted that readiness for activity in extreme situations is a systemic formation that is formed over a period of time.

A close position is maintained by M. Kotik, which defines the following structural components of psychological readiness for activity in an extreme situation: motivational (responsibility for tasks, sense of duty); orientation (knowledge and understanding of the peculiarities and conditions of activity, its requirements for personality); operating (possession of methods and techniques of activity, necessary knowledge, skills, abilities, processes of analysis, synthesis, comparison, generalization, etc.), volitional (self-control, Selfmobilization, ability to manage the actions that make up the performance of duties); evaluative (self-assessment of one's readiness and conformity of the process of performing professional tasks with the optimal models) ${ }^{2}$ (Kotyk, 2017).

A. Puni distinguished the following structural components of psychological readiness: motivational (self-confidence; desire to actively,

${ }^{2}$ Kotyk M. A. (2017). Psykholohyia y bezopasnost. [Psychology and Security]. Tallyn (in Russian). 
confidently and fully fight to achieve goals); emotional (optimal level of emotional arousal; high degree of readiness for various adverse external and internal influences); volitional (the ability to arbitrarily control their actions, thoughts, feelings, behavior in a tense atmosphere, in changing conditions) ${ }^{3}$ (Kufliievskyi \& Bolotskykh, 2010).

Thus, the researchers distinguish the following structural components: motivational, operational, cognitive, emotional, volitional, where each plays a special role in shaping the readiness of the specialist of the extreme professions for professional activity.

Interesting in the context of our study is the view of V. Sysoev, who presents the following structure of the psychological readiness of the warrior to act in extreme situations: physiological, determined by adaptive changes; technical, characterized by the level of development of the ability to perform appropriate in form and intensity of motor actions; social due to motives related to the performance of the activity; psychological, characterized by adaptive changes that occur in the human psyche due to the specific activity and requirements.

Leading, according to A. Rostunov, in the structure of psychological readiness for activity in extreme situations are the cognitive and emotional components, where the emotional state is associated with the strengthening or weakening of human cognitive activity. The strong-willed component is closely related to the purpose and quality of the activity, as well as to the previous components. According to A. Rostunov, the structure of preparedness is at the same time the structure of the mental state of readiness, and their correlation is as follows: preparedness - potential human potential and readiness the degree of mobilization. Thus, researchers establish a relationship between the cognitive, emotional, volitional components of psychological readiness to act in extreme situations.

F. Genova and E. Genov represent psychological readiness for activity in extreme situations as a state having the structure: stage-by-stage formation (the condition does not arise spontaneously, but

${ }^{3}$ Kufliievskyi A. S., \& Bolotskykh M. V. (2010). Indyvidualno-psykholohichni faktory, yaki spryiaiut uspishnosti navchalno-sluzhbovoi diialnosti kursantiv universytetu [Individual-psychological factors that contribute to the success of university students' educational and service activities] Problemy ekstremalnoi ta kryzovoi psykholohii, vol. 7, pp. 254-259. (in Ukrainian). 
must be formed consciously and purposefully, by mobilizing forces to perform precisely this activity); emotional readiness (state of mobilization readiness); time factor (forces must be used at the right time).

The researchers emphasize that the substructures of the integral structure of psychological readiness for action in an extreme situation are: biological, (adaptive changes to loads); operative (characterized by the level of development of the ability to perform appropriate in form and intensity of motor actions); activity (due to motives related to the performance of the activity); psychological (adaptation to environmental changes). Psychological readiness has a structure, which is understood as "the quality and degree of development of cognitive, emotional and volitional processes" necessary to perform a specific activity"4 (Henov \& Henova, 1973).

A. Barabanshchikov, N. Belousov argue that the state of psychological readiness arises immediately before the activities of the specialist of extreme professions. Researchers determine the following structure of psychological readiness for activity: knowledge of the task, factors that accompany the process of its implementation (danger, unexpectedness, increased responsibility, lack of time and information, etc.); ability to evaluate the influence on the human psyche of extreme factors and the changes that occur in it; techniques and ways of managing their mental states and actions in overcoming difficulties; the skills, habits, abilities and personal qualities necessary for performing various tasks and managing their emotional states; a willingness to take action.

V. Yagupov defines the following structural elements of psychological readiness for activity: motivational (the desire to overcome difficulties in a crisis or an extreme situation and understanding the need to overcome them, assessing their ability to manage mental states); cognitive (providing the necessary amount of relevant information that is necessary for purposeful and meaningful activity in extreme conditions); emotional (experiencing feelings of confidence or doubt about one's readiness to overcome difficulties); volitional (indicates the ability to overcome crises and professional

${ }^{4}$ Henov F., \& Henova E. (1973). Mobylyzatsyonnaia hotovnost y autohennaia trenyrovka sportsmena [Athlete mobilization readiness and autogenic training]. Psykholohyia y sovremennyi sport [Psychology and modern sport]. Moscow: Fyzkultura y sport Publ, pp. 242-251. (in Russian). 
difficulties); operating room (the presence of high physical abilities that allow you to successfully complete the task) $)^{5}$ (Yahupov, 2000).

Thus, scientists emphasize that the psychological readiness for a professional activity of a subject in extreme situations is the willingness of a specialist to perform professional functions in emotionally stressful situations. Let's try to generalize the structural components of psychological readiness for activity in extreme situations of professionals of extreme professions (Table 1)

Table 1

Generalized table of components psychological readiness for activity in a crisis situation of professionals of extreme professions

\begin{tabular}{|c|c|c|}
\hline $\begin{array}{c}\text { Number } \\
\text { in order }\end{array}$ & Component & \multicolumn{1}{|c|}{ Intrinsic content of components } \\
\hline 1 & 2 & \multicolumn{1}{|c|}{3} \\
\hline 1 & Motivational & $\begin{array}{l}\text { Responsibility, desire to overcome difficulties in an } \\
\text { extreme situation, stability of motive for choosing a } \\
\text { profession, understanding of a professional task, } \\
\text { importance of the chosen profession }\end{array}$ \\
\hline 2 & Operating & $\begin{array}{l}\text { Organization and isolation of directions of } \\
\text { professional activity, possession of methods and } \\
\text { techniques of activity, necessary knowledge, skills, } \\
\text { processes, analysis, synthesis, presence of high } \\
\text { physical abilities that allow to successfully accomplish } \\
\text { the task in difficult conditions }\end{array}$ \\
\hline 3 & Orientation & $\begin{array}{l}\text { Knowledge, understanding of the peculiarities and } \\
\text { conditions of the activity, its requirements for } \\
\text { personality, ability to quickly navigate in an extreme } \\
\text { situation and make informed decisions }\end{array}$ \\
\hline 4 & Evaluative & $\begin{array}{l}\text { Self-esteem of their readiness, conformity of the } \\
\text { process of performing professional tasks to the optimal } \\
\text { samples, ability to evaluate, predict the situation, } \\
\text { ability to evaluate the influence on the human psyche } \\
\text { of extreme factors and changes that occur in it }\end{array}$ \\
\hline
\end{tabular}

${ }^{5}$ Yahupov V. V. (2000). Viiskova y sotsialna psykholohiia [Military and social psychology]. Kyiv: VPTs "Kyivskyi universytet" Publ. (in Ukrainian). 
End of Table 1

\begin{tabular}{|c|c|c|}
\hline 1 & 2 & 3 \\
\hline 5 & Emotional & $\begin{array}{l}\text { Heightening or weakening emotional activity, feeling } \\
\text { obligated to complete tasks, experiencing feelings of } \\
\text { confidence or doubt in their willingness to overcome } \\
\text { difficulties, ability to be in psychological optimum and } \\
\text { abstract from emotional decisions }\end{array}$ \\
\hline 6 & Willed & $\begin{array}{l}\text { Ability to overcome difficulties, crises, anxiety, } \\
\text { developed Self-control, Self-mobilization, ability to } \\
\text { manage actions, desire for Self-improvement, } \\
\text { responsibility, independence, ability to provide the } \\
\text { necessary amount of relevant information, which is } \\
\text { necessary for purposeful and meaningful activity in } \\
\text { extreme conditions, knowledge, tasks, accompanying } \\
\text { the process of their implementation; techniques and } \\
\text { ways of managing their mental states and actions in } \\
\text { overcoming difficulties; skills, habits, skills, aptitude } \\
\text { for active action }\end{array}$ \\
\hline 7 & Cognitive & $\begin{array}{l}\text { Availability of relevant knowledge, skills, analytical, } \\
\text { prognostic, reflexive skills, developed memory } \\
\text { (motor, emotional, imaginative), creative, logical } \\
\text { thinking, attention, imagination, clarity and } \\
\text { conciseness of language, ability to verbalize one's } \\
\text { own thoughts, presence of need for increased thoughts } \\
\text { professional knowledge, creative transformation of } \\
\text { skills, developed cognitive and social activity, having } \\
\text { a clear, reasoned own position, adaptation to } \\
\text { professional activity }\end{array}$ \\
\hline
\end{tabular}

Psychological readiness for professional activity in extreme situations is manifested in knowledge, skills that are combined with personal qualities.

Scientists say that psychological preparedness for crisis situations is a set of interrelated professional, psychological and personal traits that contribute to the growth of professionalism, help to achieve quality results in the process of activity, willingness to risk and selfsacrifice, the ability to maintain self-control and self-restraint the occurrence of unforeseen obstacles. 
To analyze the formation of the psychological readiness of border guards to make decisions in extreme situations, it is necessary to conduct a psychological experiment. The experiment in psychology is used as the main method of change (in therapeutic practice), research (in science) of reality, and has traditional planning (subject to the presence of one unknown variable) and factorial (when multiple variables are unknown).

In the scientific literature distinguish the following types of psychological experiment: ascertaining (the researcher experimentally examines only the existence of connections, dependencies between phenomena, determines the initial data of the study); molding (accompanied by the application of a specially designed system of measures aimed at the formation of certain qualities, etc.); control (determines the level of knowledge, skills and skills based on the materials of the forming experiment). The leading task of the psychological experiment is to make changes in the educational process according to the content of the study; creation of conditions in which the connections between different phenomena under study are most clearly presented; accounting for the results of the change process and conclusions ${ }^{6}$ (Lavrentieva \& Shyshkina, 2007).

Accordingly, it is of great importance to organize experimental work in schools, which should have a clear fixation of the starting conditions; formulation of the hypothesis and expected results; fixing independent variables; fixing the experimental conditions, determining the results and matching their hypotheses.

Establishing the essence of the psychological experiment and the place in it of the ascertaining and formative stages will allow to determine the level of formation of the psychological readiness of the border guards to make a decision in an extreme situation, to develop a program aimed at the formation of this phenomenon.

To find out the level of preparedness of border guards for decision-making in extreme situations, students and students were offered the following questionnaire: "Psychological readiness for

${ }^{6}$ Lavrentieva H. P., \& Shyshkina M. P. (2007). Metodychni rekomendatsii z orhanizatsii ta provedennia naukovo-pedahohichnoho eksperymentu [Guidelines for the organization and conduct of scientific and pedagogical experiment]. Kyiv: PTZN Publ. (in Ukrainian). 
decision-making in extreme situations"; questionnaire "Emotional state"; a test for determining knowledge of the psychological preparation of future border guards for an extreme situation.

The basis of the questionnaire is to determine the formation of psychological readiness for decision making in extreme situations, which may depend on the presence of a number of motives:

- social motives that contribute to the formation of psychological readiness for decision making in extreme situations, given the importance of the profession, are dependent on the assessment of others;

- professional motives that encourage the acquisition of specific knowledge, skills and competences that are professionally relevant (psychological readiness for decision-making in extreme situations makes it possible to pursue professional activity at a higher level, promotes competitiveness, career growth);

- cognitive motives - interest in self-knowledge, understanding of the value of knowledge of the surrounding world, internal need for self-improvement, self-development;

- social identification, the importance of one's profession in the eyes of others, and a positive attitude;

- pragmatic motives - acquired knowledge will promote career development;

The questionnaire "Psychological readiness for decision-making in extreme situations" should include the following questions:

1. Are you familiar with the concept of "Psychological readiness"?

2. Are you aware of the problem of decision-making in extreme situations?

3. Does the study of disciplines taught at the university contribute to the psychological readiness for decision-making in extreme situations?

4. Do you consider psychological readiness a condition for making a constructive decision in extreme situations?

6. Does your emotional state affect your emergency preparedness?

The questionnaire "Psychological readiness for decision-making in extreme situations" should include the following questions:

1. Are you familiar with the concept of "Psychological readiness"? 
2. Are you aware of the problem of decision-making in extreme situations?

3. Does the study of disciplines taught at the university contribute to the psychological readiness for decision-making in extreme situations?

4. Do you consider psychological readiness a condition for making a constructive decision in extreme situations?

5 . Does your emotional state affect your emergency preparedness?

The questionnaire "Emotional state" allowed to reveal negative emotional states as indicators of existing emotional problems that may interfere with the formation of psychological readiness to be in an extreme situation. Thus, for a border guard who has psychological problems, forming readiness for decision-making in extreme situations is a "cornerstone" of his activity.

Psychological factor is the leading in the activity of the border guard, because the presence of depressive manifestations, aggression, emotional instability can lead to complex consequences in professional activity. Questionnaire "Emotional state" allowed us to assess the presence of the above states, and thus personal problems.

The concept of "Personal problem" is briefly outlined - the subject cannot solve the problem on his own due to the lack of awareness of its preconditions. Personal problem and causes the inability to perform a particular activity due to the presence of conditional values, unconscious motives, traumatic experiences of childhood, etc. ${ }^{7}$

A personal problem can interfere with the objective perception of others and others. This problem causes the inability of the subject to take responsibility, to manage their emotions, to work constructively with others, to have partnerships, a stable state of health in stressful situations and professional interaction.

The Emotional Status questionnaire provided information about:

- the presence of a psychological problem that causes negative emotional states;

7 Binkovskyi O. A., \& Zhdanenko O. A., \& Serdiuk Yu. I. \& oth. (2010). Kultura prykordonnoho kontroliu $v$ punktakh propusku cherez derzhavnyi kordon Ukrainy : navch. Posib [The Culture of Border Control at Crossing Points at the State Border of Ukraine: Tut. tool]. Khmelnytskyi : NADPSU Publ. (in Ukrainian). 
- the level of development of the emotional sphere, the presence of optimism, psychological flexibility, mobility, etc .;

- the ability to constructively cooperate and the ability to take responsibility without the influence of emotional factors;

- ability to manage their own emotions, peculiarities of perception of an extreme situation and ability to make a constructive decision in an emotionally difficult situation;

- Adaptation opportunities, in particular the ability to overcome difficulties in an extreme situation, the absence of negativism, activity, etc.

- the presence of psychological Self-regulation skills.

The developed questionnaires are based on the principles of: taking into account the peculiarities of the respondent's perception of the text of the questionnaire; the focus of the questions on the problem under study; clarity and structure of content blocks. The questionnaire has such conditional content blocks as: analysis of emotional state, level of development of emotional sphere, adaptive abilities and Selfcontrol. For the convenience of processing the results of the questionnaire, an assessment scale from 1 to 10 was selected. The results of the questionnaires "Psychological readiness for decision making in extreme situations" and "Emotional state" were calculated on a 10 -point scale: from 1 to 4 points - low, from 5 to 7 points average, from 8 to 10 points - high.

The questionnaire "Psychological preparedness for decision making in extreme situations" was calculated according to the following indicators: low level - low awareness of the problem of psychological readiness for risk, decision making in extreme situations; low interest in professional development; unwillingness to acquire psychological knowledge. Respondents with intermediate levels had a vague knowledge of the issue of psychological risk readiness and decision making in extreme situations; the relative desire to develop psychological knowledge. The high level was characterized by a high awareness of the problem of psychological readiness for risk, the issue of decision-making in extreme situations; the desire to develop knowledge in the field of psychology.

The results of the questionnaire "Emotional state" were calculated according to the following indicators: 1-6 points - presence of negative emotional state, depressive states, feeling of loneliness, 
emotional closeness, aggressiveness, dissatisfaction with life, low adaptability; 7-10 points - positive emotional state, openness to new experiences, activity, high adaptability, ability to emotional load.

Application of the Reactive (Situational) and Personal Anxiety Scale Spielberger, Yu. L. Hanina will allow to analyze the adaptive capabilities of the subject. Self-control and Self-esteem of anxiety are an essential component of adaptive personality behavior, in particular a border guard specialist. It is well known that anxiety is a major indicator of the ability to adequately make decisions in extreme situations. The techniques allow us to identify a set of personality traits that allow the frontier to tolerate the effect of stressors without harmful bursts of emotions that affect activity and may cause mental disorders. It is established that high stress resistance is characterized by low level of emotionality, which can lead to callousness, lack of emotions, indifference, closedness and the appearance of depressive tendencies.

The presence of high personal anxiety is an indicator that a specialist may misinterpret information coming from outside and interpret it as threatening. Such distortion leads to difficulties in making a balanced decision in an extreme situation, because it is based on the emotions of fear.

Test "Diagnosis of strategies for behavioral activity in stressful conditions". Diagnosis of strategies for behavioral activity in stressful conditions allows you to determine the type of personality, its tendency to respond to a certain type of reaction in extreme conditions. This test allows you to: assess the subject's need for activity (depression or vice versa); initiative or lack of action during stress; anxiety, aggression, or depression; feeling of constant tension; inability to relax; negativism or deviation from reality; inability to sustained tension or vice versa; endurance and high Self-regulation; high motivation to achieve the goal, etc. Yes, the test reveals behavioral responses of type (A): it is a personality with unstable emotional reactions, impatient, impulsive personality, which in stressful conditions are incapable of making informed decisions. Such a person is capable of aggressive reactions and in extreme situations can show unexpected reactions.

Type A.1 is characterized by competitiveness, business activity, impatience, which in the activity of the border guard can find expression in conflict, aggressiveness, etc. Individuals of this type have a weak nervous system and thus have difficulty in being in an extreme 
situation. It is difficult for such individuals to cope with anxiety, and a life-threatening situation can be viewed as catastrophic.

In contrast, there are two other types (AB and $\mathrm{B}$ ) characterized by emotional stability, Self-confidence, rationality, caution, moderate activity, and so on. Future border guards with these types of personalities are effective for staying in psychologically challenging environments with increased stress and risk to life.

The technique "Diagnosis of the type of emotional response to the influence of environmental stimuli" also allows you to analyze the persistent or unstable behavior of a person, confidence, ability to respond adequately to critical situations.

The technique was used because of its ability to determine the type of emotional response of the individual that is needed in the activities of the future border guard. The border guard who is in an extreme situation requires immediate decision making, responsibility, self-confidence, emotional stability and so on. Borderline emotional reactions can play a major role in his professionalism.

The test contributes to the definition of such positions as "euphoric position outside", which implies a positive attitude to life, openness, activity, a high level of emotional Self-regulation and so on. The future border guard who has a high score, reflective activity in the middle, a person is passive, fixates on the little things, long plans his own actions and difficult to implement them, has difficulty making decisions, shows aggression and anxiety without high level irritant.

A close preliminary character is dysphoric activity outside, which is manifested in irritability, aggressiveness, unrestrainedness, hostility, negativity towards life, inability to take responsibility, depressive position, etc. Thus, the last two types need to undergo psychocorrectional training and work directly on these individuals.

In the process of introducing a test for determining the knowledge of the psychological preparation of future border guards for an extreme situation, the uniformity of their distribution is taken into account by the complexity of perception by cadets and students. Below is a sample of test tasks designed by Lytvynchuk M. Yu. ${ }^{8}$ (Lytvynchuk, 2018a).

8 Lytvynchuk M. Yu. (2018). Formuvannia psykholohichnoi hotovnosti maibutnikh prykordonnykiv do pryiniattia rishennia $v$ kryzovykh sytuatsiiakh [Formation of psychological readiness of future border guards for decision-making 
The test questions were based on the cognitive and motivational components of psychological readiness to make decisions in extreme conditions. The test allows to ascertain the presence of analytical thinking (logically analyze and organize the material obtained). So the test question "Psychological readiness for action in extreme situations" provides a number of answers:

a) a set of professional and personal qualities that enable a specialist to effectively interact with others during a psychologically difficult situation, facilitate its successful resolution by making a well-considered decision;

b) professionalism, desire to work in a psychologically difficult situation;

c) timely decision-making in a particular situation, in accordance with the motives, goals and objectives of the activity.

The question presented involves testing your knowledge of the problem of psychological readiness to act in extreme situations. Although the answer options have similar semantics, the answer to the right question must be determined quickly.

The following questions are intended not only to test the standard knowledge, but also the specifics of the border guards' professional activity $^{9}$ (Lytvynchuk, 2018b).

So the test question "emergency" is: a) a situation in a certain territory as a result of an accident, catastrophe, natural disaster, entails human casualties, carries damage to human health or the environment, significant material loss and disruption of life people; b) catastrophe, a natural disaster that entails human sacrifice; c) threat to human health or the environment.

A 100-point scale was developed to test the psychological readiness test for the extreme, where: 1 to 30 points - low level of knowledge: no correct answer -1 point, 3 correct answers -10 points, 5 correct answers - 30 points; from 30 to 60 points - average: 6 correct

in crisis situations] (PhD Thesis), Kyiv: GS Institute of Psychology Kostyuk NAPN of Ukraine (in Ukrainian).

9 Lytvynchuk M. Yu. (2018). Formuvannia psykholohichnoi hotovnosti maibutnikh prykordonnykiv do pryiniattia rishennia $v$ kryzovykh sytuatsiiakh [Formation of psychological readiness of future border guards for decision-making in crisis situations] (PhD Thesis). Kyiv: GS Institute of Psychology Kostyuk NAPN of Ukraine (in Ukrainian). 
answers - 40 points, 8 correct answers - 50 points, 10 correct answers -60 points; from 60 to 90 points - a high level of knowledge: received the right answers to almost all questions -70 points, the right answers to all questions - 80 points, the correct answers to all questions with creative disclosure of their content $-90-100$ points. The qualitative analysis of the questioning and testing takes into account the correctness of the answers, knowledge of theoretical material and awareness of the possibilities of its use.

Studying the level of formation of psychological readiness for decision-making by the future border guard in extreme conditions requires delineation of a set of criteria of their indicators and correlation with the chosen research methods (Table 2).

The future border guard must distinguish between crisis and extreme situations; understand the psychological features of the impact of the crisis on the psyche of the individual; to know the features of decision-making in extreme situations, the role of psycho-traumatic factors in the activities of border guards, etc.

Table 2

The ratio of the criteria of psychological readiness

for decision-making by the future border guard in extreme conditions and selected methods of diagnosis

\begin{tabular}{|c|c|c|c|}
\hline $\begin{array}{l}\text { Number } \\
\text { in order }\end{array}$ & Criterion & Indicator & Method \\
\hline 1 & 2 & 3 & 4 \\
\hline 1 & 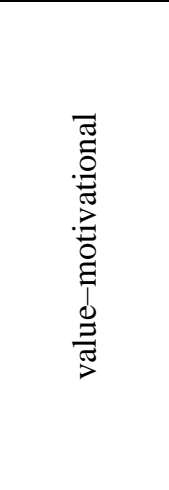 & $\begin{array}{l}\text { availability of motives } \\
\text { for learning and } \\
\text { personal development; } \\
\text { the need to form a } \\
\text { psychological } \\
\text { readiness for decision } \\
\text { making, a sense of the } \\
\text { value and importance } \\
\text { of one's profession; } \\
\text { desire to succeed, } \\
\text { motivation for social } \\
\text { activity }\end{array}$ & $\begin{array}{l}\text { Test Determining Knowledge } \\
\text { of Psychological Preparation } \\
\text { of Future Border Guards for } \\
\text { Extreme Situation " } \\
\text { Test "Diagnosis of behavioral } \\
\text { strategies in stressful } \\
\text { conditions" } \\
\text { Methodology "Diagnosis of } \\
\text { emotional reaction type on } \\
\text { influence of environmental } \\
\text { stimuli }\end{array}$ \\
\hline
\end{tabular}


End of Table 2

\begin{tabular}{|c|c|c|c|}
\hline 1 & 2 & 3 & 4 \\
\hline 2 & 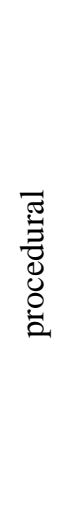 & $\begin{array}{l}\text { advanced } \\
\text { organizational skills, } \\
\text { knowledge of decision- } \\
\text { making algorithm, } \\
\text { ability to analyze, } \\
\text { organize and } \\
\text { summarize information } \\
\text { ability for professional } \\
\text { and personal growth, } \\
\text { development of social- } \\
\text { perceptual intelligence, } \\
\text { ability to act outside } \\
\text { the pattern }\end{array}$ & $\begin{array}{l}\text { Questionnaire "Psychological } \\
\text { readiness for decision- } \\
\text { making in extreme } \\
\text { situations" } \\
\text { Test "Scale of reactive } \\
\text { (situational) and personal } \\
\text { anxiety Spielberger, } \\
\text { Y. L. Hanin" }\end{array}$ \\
\hline 3 & 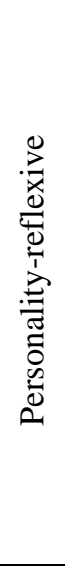 & $\begin{array}{l}\text { ability for professional } \\
\text { and personal growth, } \\
\text { development of social- } \\
\text { perceptual intelligence, } \\
\text { ability to act outside } \\
\text { the pattern }\end{array}$ & $\begin{array}{l}\text { Questionnaire "Psychological } \\
\text { readiness for decision- } \\
\text { making in extreme } \\
\text { situations" } \\
\text { questionnaire "Emotional } \\
\text { state" } \\
\text { test "Scale of reactive } \\
\text { (situational) and personal } \\
\text { anxiety Spielberger, } \\
\text { Y. L. Hanin " } \\
\text { Methodology "Diagnosis of } \\
\text { emotional reaction type on } \\
\text { influence of environmental } \\
\text { stimuli }\end{array}$ \\
\hline 4 & 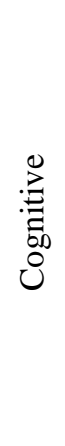 & $\begin{array}{l}\text { Knowledge, ability, } \\
\text { skill, desire for } \\
\text { self-development, } \\
\text { self-improvement }\end{array}$ & $\begin{array}{l}\text { Questionnaire "Psychological } \\
\text { readiness for decision- } \\
\text { making in extreme } \\
\text { situations" } \\
\text { Test "Determination of stress } \\
\text { resistance by the method of } \\
\text { S. Cowan and G. Willianson" } \\
\text { Questionnaire "Psychological } \\
\text { readiness for decision- } \\
\text { making in extreme } \\
\text { situations" }\end{array}$ \\
\hline
\end{tabular}


A significant indicator is the attitude of the military to their profession, their activities, their mutual assistance, their ability to trust others, their level of awareness of political events, and more.

\section{CONCLUSIONS}

The article revealed that the future border guard should be able to analyze the motivation of their own activities and justify the decision made, determine the level of professional and professional capacity of colleagues, etc.

Studying the system of psychological training at the National Academy of the State Border Guard Service of Ukraine gave grounds for distinguishing the following features: the presence of a system of psychological training of students and cadets for extreme conditions; availability of programs for psychological training of cadets and students of professional activity; system of measures to stimulate cadets to increase the level of psychological readiness for activity in extreme conditions; creation of conditions for motivation of future border guards for the development of psychological knowledge.

Border guards must be able to cooperate constructively with colleagues, have social-perceptual intelligence, show empathy, conflict-free communication, convey information received during operational operations, use knowledge of psychology in advising the population about extreme situations, etc.

We have reason to say that the low level of psychological readiness for decision-making in extreme situations is largely due to the poor motivation of future border guards, the lack of proper educational and methodological support.

\section{SUMMARY}

The article presents the psychological aspects of the formation of readiness for decision-making in extreme situations by border guards. It is emphasized that the psychological readiness for the professional activity of the subject in extreme situations consists in the willingness of a specialist to perform professional functions in emotionally stressful situations. It has been established that the main structural components of psychological readiness for professional activity are motivational, professional, operational, cognitive and cognitive. An attempt is made to generalize the structural components of 
psychological preparedness for extreme professions to work in extreme situations. The study of the psychological training system at the National Academy of the State Border Service of Ukraine gave reason to highlight its features: the presence of a system of psychological preparation for staying in extreme conditions; the availability of psychological training programs for cadets and students of professional activities; a system of measures to stimulate cadets to increase the level of psychological preparedness for activities in extreme conditions; creating conditions for motivating future border guards to the development of psychological knowledge. The correlation of criteria of psychological readiness for decision-making by future border guards in extreme conditions and the selected diagnostic methods is revealed.

\section{REFERENCES}

1. Almukhanova, A. B. \& oth. (2007). Bol'shaya psykholohycheskaya эntsyklopedyya : samoe polnoe sovremennoe yzdanye : Bolee 5000 psykholohycheskykh termynov y ponyatyy [Big psychological encyclopedia: the most complete modern publication: More than 5000 psychological terms and concepts]. Moscow: Эksmo Publ. (in Russian).

2. Binkovskyi O. A., \& Zhdanenko O. A., \& Serdiuk Yu. I. \& oth. (2010). Kultura prykordonnoho kontroliu $v$ punktakh propusku cherez derzhavnyi kordon Ukrainy : navch. Posib [The Culture of Border Control at Crossing Points at the State Border of Ukraine: Tut. tool]. Khmelnytskyi : NADPSU Publ. (in Ukrainian).

3. Henov F., \& Henova E. (1973). Mobylyzatsyonnaia hotovnost y autohennaia trenyrovka sportsmena [Athlete mobilization readiness and autogenic training]. Psykholohyia y sovremennyi sport [Psychology and modern sport]. Moscow: Fyzkultura y sport Publ, pp. 242-251. (in Russian).

4. Kotyk M. A. Psykholohyia y bezopasnost. [Psychology and Security]. Tallyn (in Russian).

5. Kufliievskyi A. S., \& Bolotskykh M. V. (2010). Indyvidualnopsykholohichni faktory, yaki spryiaiut uspishnosti navchalnosluzhbovoi diialnosti kursantiv universytetu [Individual-psychological factors that contribute to the success of university students' educational and service activities] Problemy ekstremalnoi ta kryzovoi psykholohii,vol. 7, pp. 254-259. (in Ukrainian). 
6. Lavrentieva H. P., \& Shyshkina M. P. (2007). Metodychni rekomendatsii $z$ orhanizatsii ta provedennia naukovo-pedahohichnoho eksperymentu [Guidelines for the organization and conduct of scientific and pedagogical experiment]. Kyiv: PTZN Publ. (in Ukrainian).

7. Lytvynchuk M. Yu. (2018). Formuvannia psykholohichnoi hotovnosti maibutnikh prykordonnykiv do pryiniattia rishennia $v$ kryzovykh sytuatsiiakh [Formation of psychological readiness of future border guards for decision-making in crisis situations] ( $\mathrm{PhD}$ Thesis). Kyiv: GS Institute of Psychology Kostyuk NAPN of Ukraine (in Ukrainian).

8. Yahupov V. V. (2000). Viiskova y sotsialna psykholohiia [Military and social psychology]. Kyiv: VPTs "Kyivskyi universytet" Publ. (in Ukrainian).

Information about the author: Lesia Lytvynchuk

$\mathrm{PhD}$ in Psychology, Senior Researcher National Academy of the State Border Guard Service of Ukraine named after Bohdan Khmelnytskyi 46, Shevchenko str., Khmelnytskyi, 29003, Ukraine ORCID ID: orcid.org/0000-0002-5085-4499 E-mail: lutol@ukr.net 